\title{
Angiokeratoma of Fordyce
}

National Cancer Institute

\section{Source}

National Cancer Institute. Angiokeratoma of Fordyce. NCI Thesaurus. Code C7752.

An angiokeratoma that is located on the scrotum. 